\title{
Pengaruh Komunikasi Pemasaran Produk melalui Instagram @ Anakjajan terhadap Perilaku Followers
}

\author{
Glenn Jonathan ${ }^{1}$, Yugih Setyanto ${ }^{2 *}$ \\ ${ }^{1}$ Fakultas Ilmu Komunikasi, Universitas Tarumanagara, Jakarta \\ Email: glenn.915130162@stu.untar.ac.id \\ ${ }^{2}$ Fakultas Ilmu Komunikasi, Universitas Tarumanagara, Jakarta* \\ Email:yugihs@fikom.untar.ac.id
}

Masuk tanggal : 15-12-2021, revisi tanggal : 06-01-2022, diterima untuk diterbitkan tanggal : 16-01-2022

\begin{abstract}
Instagram is a social media that is currently widely used by the public. This research looks at how the product marketing communication carried out by @Anakjajan affects the behavior of his followers. This research approach is quantitative. This study used a survey method on Instagram followers of @ Anakjajan account. The population in this study were followers of @ Anakjajan. In this study, the sample used was 77 people who would become respondents to the research survey. The data were processed using descriptive statistical analysis techniques. The results concluded that product marketing communication through Instagram @ Anakjajan has a positive effect on cognitive and affective effects while the conative effect has a neutral result.
\end{abstract}

Keywords: consumer behavior, Instagram, marketing communication

\begin{abstract}
Abstrak
Instagram merupakan media sosial yang saat ini banyak digunakan oleh masyarakat. Penelitian ini melihat bagaimana komunikasi pemasaran produk yang dilakukan @Anakjajan berpengaruh terhadap perilaku followersnya. Pendekatan penelitian ini adalah kuantitatif. Penelitian ini menggunakan metode survey pada followers Instagram akun @ Anakjajan Populasi dalam penelitian adalah followers @ Anakjajan. Dalam penelitian ini sampel digunakan berjumlah 77 orang yang akan menjadi responden survey penelitian. Data diolah dengan teknik analisis statistik deskriptif. Hasilnya disimpulkan bahwa komunikasi pemasaran produk melalui Instagram @ Anakjajan berpengaruh positif pada efek kognitif dan afektif sedangkan pada efek konatif memiliki hasil netral.
\end{abstract}

Kata Kunci: Instagram, komunikasi pemasaran, perilaku konsumen

\section{Pendahuluan}

Menurut Kotler dan Keller, pemasaran adalah proses sosial dimana di dalamnya ada individu dan kelompok yang mendapatkan apa yang dibutuhkan dengan mempertukarkan produk kepada pihak yang lain (Limakrisna, Susilo, 2012:3). Donald $\mathrm{K}$. Robert menyatakan bahwa ada yang beranggapan bahwa "efek hanyalah perubahan perilaku manusia setelah diterpa pesan media massa". Oleh karena fokusnya pesan, maka efek harus berkaitan dengan pesan yang disampaikan media massa (Ardianto, 2004: 48).

Pesan yang disampaikan melalui media massa memberikan dampak atau efek terhadap khalayak. Terdapat tiga dimensi efek komunikasi massa, yakni kognitif, afektif, dan konatif. Efek kognitif menyangkut pikiran atau penalaran, sehingga 
khalayak yang semula tidak tahu, yang tadinya tidak mengerti, akan menjadi lebih jelas, sehingga memberikan pengetahuan baru kepada khayalak. Efek afektif menyangkut dengan perasaan. Diantaranya adalah perasaan seperti senang dan menyebabkan tersenyum bahkan sampai tertawa lepas, ditambah dengan perasaan sedih bahkan sampai menangis.

Sedangkan pada komunikasi pemasaran, terdapat beberapa tujuan, yaitu perubahan sikap dan pernyataan terhadap suatu objek. Perubahan sikap ditentukan oleh tiga komponen yaitu kognitif dimana konsumen mengubah pandangannya terhadap suatu produk, lalu afektif yaitu berubahnya perasaan tertentu dari konsumen, dan konatif yaitu melakukan kecendrungan mengambil keputusan untuk melakukan atau tidak.

Instagram adalah sebuah media sosial yang sedang digemari oleh masyarakat berbagai kalangan. Dengan mengunggah foto di Instagram, foto tersebut dapat diedit dengan menerapkan filter digital sehingga visualnya lebih menarik dan dapat dibagikan kepada pengguna lainnya. Keunggulan instagram adalah kemampuannya menghubungkan foto yang memiliki hashtag dengan pengguna yang mencari hashtag tersebut.

Salah satu food blogger yang terkenal di Jakarta adalah Marius dengan akun Instagram @iammarius mengembangkan akun@Anakjajan. Ia mendistribusikan foto dengan tema kuliner serta destinasi kuliner sebanyak 10.700 foto dan memiliki pengikut yang mencapai lebih dari 400.000 orang. Akun ini mendapat respon positif dari pengikutnya di setiap postingannya, dilihat dari tanda "like" di postingannya yang mencapai angka ribuan. Setiap hari akun @ Anakjajan mengunggah foto lebih dari sekali dengan foto yang berbeda sesuai dengan perkebangan jaman.

Dari seluruh penjelasan diatas dapat dirangkum bahwa penelitian ini dilakukan untuk mengetahui berapa besar respon kognitif, afektif, dan konatif dari pengikut @ Anakjajan mengenai pemasaran produk kuliner.

\section{Metode Penelitian}

Penelitian kuantitatif adalah sebuah penelitian dengan menggunakan angkaangka dari pengumpulan data sampai hasil penelitiannya. Berdasarkan definisi diatas peneliti akan menggunakan metode penelitian dengan pendekatan kuantitatif.

Metode penelitian yang dilakukan pada penelitian ini adalah dengan metode kuantitatif yang menggunakan survey. Penelitian ini menggunakan kuesioner yang diharapkan dapat memperoleh informasi dari responden.

Menurut (Sugiyono 2008: 115), populasi didefinisikan sebagai suatu wilayah generalisasi yang dimuat oleh obyek serta subyek yang memiliki kualitas dan karakteristik tertentu sehingga dapat ditentukan oleh peneliti agar dapat teliti sehingga memperoleh kesimpulan. Populasi dalam penelitian adalah Followers dari akun media sosial Instagram @ Anakjajan

Sampel adalah sebagian dari jumlah dan karakteristik yang dimiliki oleh populasi tersebut (Sugiyono 2008: 116), sehingga sampel merupakan sebagian dari populasi yang ada. Dengan demikian karakteristiknya harus diselidiki dengan cara tertentu.

Metode pengumpulan data yang digunakan dalam penelitian ini adalah survey. Dalam penelitian ini menggunakan metode survey pengumpulan data yaitu Metode pengumpulan data yang digunakan dalam penelitian ini adalah survey. Dalam penelitian ini menggunakan metode survey pengumpulan data yaitu kuesioner. 
Glenn Jonathan, Yugih Setyanto: Pengaruh Komunikasi Pemasaran Produk melalui Instagram @ Anakjajan terhadap Perilaku Followers

Kuesioner merupakan teknik pengumpulan data yang dilakukan dengan cara memberi seperangkat pertanyaan atau pernyataan tertulis kepada responden untuk dijawab (Sugiyono 2013: 199)

Untuk melanjutkan penelitian ini, penulis menggunakan analisis statistik deskriptif. Analisis statistik deskriptif adalah statistik yang digunakan dalam menganalisis data dengan cara mendeskripsikan atau menggambarkan data yang telah terkumpul dari nilai rata-rata(mean), standar deviasi, varian, maksimum, minimum, sum, kurtosis, dan skewness atau kemencengan distribusi. analisis ini berfungsi untuk mendeskripsikan atau memberi gambaran terhadap objek yang diteliti melalui populasi dan data sampel.

Untuk mencapai tujuan penelitian, dibutuhkan pengujian untuk membuktikan bahwa data penelitian ini valid dan reliabel, maka penulis melakukan uji validitas dan uji reliabilitas.

\section{Hasil Temuan dan Diskusi}

Penelitian ini menggunakan analisis deskriptif yang disajikan dalam tabel distribusi frekuensi sederhana (simple frequency distri bution). Tampilan data pada distribusi frekuensi terdiri dari tiga kolom yaitu variabel, frekuensi, dan presentasi. Analisis deskriptif digunakan untuk membahas efek dari followers akun Instagram @ Anakjajan.

Tabel 1. Responden

\begin{tabular}{ccc}
\hline Uraian & Frekuensi & Persentase \\
\hline Pria & 27 & $35 \%$ \\
\hline Wanita & 50 & $65 \%$ \\
\hline Total & 77 & $100 \%$
\end{tabular}

Sumber: Hasil Olah Data Peneliti

Berdasarkan tabel diatas, makan bisa dilihat bahwa hasil mayoritas responden adalah wanita sebesar $65 \%$. Jadi berdasarkan penelitian ini, wanita lebih banyak dibanding pria.

Tabel 2. Responden

\begin{tabular}{ccc}
\hline Uraian & Frekuensi & Persentase \\
\hline 12-16 Tahun & 3 & $4 \%$ \\
\hline 17-25 Tahun & 60 & $78 \%$ \\
\hline 26-35 Tahun & 14 & $18 \%$ \\
\hline Total & 77 & $100 \%$ \\
\hline
\end{tabular}

Sumber: Hasil Olah Data Peneliti

Berdasarkan tabel diatas, maka bisa dilihat bahwa hasil mayoritas responden berkisar antara umur 17-25 tahun dengan persentase sebesar 78\%.

Berdasarkan hasil uji validitas terhadap 17 item kuisioner efek dari followers akun Instagram @Anakjajan, terlihat bahwa keseluruhan hasil item kuisioner memiliki nilai yang lebih besar daripada nilai $r$ tabel untuk 77 responden, yaitu 0,224. Karena terhitung lebih besar daripada $\mathrm{r}$ tabel, maka 17 pertanyaan tersebut dinyatakan valid. 
Tabel 3. Hasil Uji Validitas 17 butir Kuisioner

Efek Followers Akun Instagram @ Anakjajan

\begin{tabular}{|c|c|c|}
\hline & & Response \\
\hline $\begin{array}{c}\text { Kog } \\
-1\end{array}$ & $\begin{array}{l}\text { Pearson Correlation } \\
\text { Sig. (2-tailed) } \\
\text { N }\end{array}$ & $\begin{array}{l}.724 * * \\
.000 \\
77\end{array}$ \\
\hline $\begin{array}{l}\text { Kog } \\
-2\end{array}$ & $\begin{array}{l}\text { Pearson Correlation } \\
\text { Sig. (2-tailed) } \\
\text { N }\end{array}$ & $\begin{array}{l}.831 * * \\
.000 \\
77\end{array}$ \\
\hline $\begin{array}{l}\text { Kog } \\
-3\end{array}$ & $\begin{array}{l}\text { Pearson Correlation } \\
\text { Sig. (2-tailed) } \\
\text { N }\end{array}$ & $\begin{array}{l}.816^{* *} \\
.000 \\
77\end{array}$ \\
\hline $\begin{array}{l}\text { Kog } \\
44\end{array}$ & $\begin{array}{l}\text { Pearson Correlation } \\
\text { Sig. (2-tailed) } \\
\text { N }\end{array}$ & $\begin{array}{l}.786^{* *} \\
.000 \\
77\end{array}$ \\
\hline $\begin{array}{l}\text { Kog } \\
-5\end{array}$ & $\begin{array}{l}\text { Pearson Correlation } \\
\text { Sig. (2-tailed) } \\
\text { N }\end{array}$ & $\begin{array}{l}.692 * * \\
.000 \\
77\end{array}$ \\
\hline $\begin{array}{l}\text { Kog } \\
66\end{array}$ & $\begin{array}{l}\text { Pearson Correlation } \\
\text { Sig. (2-tailed) } \\
\text { N }\end{array}$ & $\begin{array}{l}.761^{* *} \\
.000 \\
77\end{array}$ \\
\hline $\begin{array}{l}\text { Kog } \\
-7\end{array}$ & $\begin{array}{l}\text { Pearson Correlation } \\
\text { Sig. (2-tailed) } \\
\text { N }\end{array}$ & $\begin{array}{l}.782 * * \\
.000 \\
77\end{array}$ \\
\hline $\begin{array}{l}\text { Afek } \\
-1\end{array}$ & $\begin{array}{l}\text { Pearson Correlation } \\
\text { Sig. (2-tailed) } \\
\mathrm{N}\end{array}$ & $\begin{array}{l}.777 * * \\
.000 \\
77\end{array}$ \\
\hline
\end{tabular}

\section{Sumber: Hasil Olah Data Peneliti}

Berdasarkan hasil uji reliabilitas terhadap 17 item kuisioner efek dari followers akun Instagram@Anakjajan, terlihat bahwa nilai cronbach's alpha adalah 0,940. Nilai $r$ kritis (uji 2 sisi) pada signifikasi 0.05 dengan jumlah data 17 butir, maka di dapat sebesar 0,482. Karena r-hitung > r-tabel $(0,940>0,482)$, maka hasil dari uji reliabilitas ini bisa disimpulkan bahwa keseluruhan butir penelitian ini adalah reliable.

Tabel 4. Hasil Uji Reliabilitas 17 Butir Kuesioner

Efek dari Followers akun Instagram @ Anakjajan

\begin{tabular}{cc}
\hline $\begin{array}{c}\text { Cronbach's } \\
\text { Alpha }\end{array}$ & N of Items \\
\hline .940 & 17 \\
\hline Sumber: Hasil Olah Data Peneliti
\end{tabular}


Berdasarkan hasil yang didapat dari penelitian oleh peneliti, maka dapat diketahui efek kognitif yang paling tinggi adalah indicator kognitif 1 sebesar 70\% (54orang) responden yang menyatakan setuju bahwa responden mengetahui bahwa akun Instagram @Anakjajan adalah akun wisata kuliner.

Berdasarkan hasil yang didapat dari penelitian oleh peneliti, maka dapat diketahui efek afektif yang paling tinggi adalah indikator afektif 1 sebesar 66\% (51orang) responden. Responden menyatakan bahwa konten foto kuliner yang ditampilkan@Anakjajan sangat menarik. Berarti dalam hal ini, @Anakjajan telah berhasil dalam menciptakan gambar-gambar yang menarik minat responden.

Berdasarkan hasil yang didapat dari penelitian oleh peneliti, maka dapat diketahui efek konatif yang paling tertinggi tingkat setujunya adalah indikator konatif 1 dengan persentase setuju sebesar 51\% (49orang) responden yang menyatakan bahwa responden selalu mengikuti informasi tebaru yang di unggah oleh @ Anakjajan.

\section{Simpulan}

Dalam penelitian ini melalui data serta pembahasan yang sudah dilaksanakan melalui proses penelitian, penulis mengambil kesimpulan berikut. Dari hasil keseluruhan ketiga efek tersebut, yaitu kognitif, afektif dan konatif, maka didapatkan bahwa efek kognitif dan afektif mendapatkan hasil yang positif dari para followers, sedangkan efek konatif mendapatkan hasil yang netral atau ragu-ragu dari para follower.

\section{Ucapan Terima Kasih}

Peneliti ingin mengucapkan terima kasih kepada Fakultas Ilmu Komunikasi Universitas Tarumanagara, narasumber, serta semua pihak yang turut membantu peneliti sehingga penelitian ini dapat diselesaikan.

\section{Daftar Pustaka}

Ardianto, E., \& Komala, L. (2004). Komunikasi massa: suatu pengantar. Simbiosa Rekatama Media.

Limakrisna, N., \& Susilo, W. H. (2012). Manajemen Pemasaran Teori dan Aplikasi dalam Bisnis. Jakarta: Mitra Wacana Media.

Sugiyono. (2013). Metode Penelitian Bisnis. Bandung: Penerbit Alfabeta.

Sugiyono, D. (2010). Metode penelitian kuantitatif dan R\&D. Bandung: Alfabeta.

Sugiyono. (2013). Metode Penelitian Kombinasi. Bandung: Alfabeta. 